\title{
FUNGSI KOMUNIKASI MASSA DALAM TELEVISI (Studi Kasus Program Acara 'Bukan Empat Mata' di TRANS 7)
}

\author{
Hastika Yanti Nora \\ M.Chaerul Latief \\ (kaneea_pink@yahoo.co.id) \\ Yuliyanto Budi Setiawan (youlee_wa2n@yahoo.co.id) \\ Tim Penelitian Dosen Jurusan Ilmu Komunikasi Universitas Semarang
}

\begin{abstract}
This research is conducted to described and verified communication functions on television program called 'Bukan Empat Mata' on Trans7. This research used survey method. Primary data gathered from questionnaires, while secondary data collected from related literatures. Research final gains, showing that 'Bukan Empat Mata' serves two mass-communication functions, which are surveillance and linkage functions from media upon society, especially 'Bukan Empat Mata' audiences come from Semarang University academics.
\end{abstract}

Keywords: mass-communication functions, television program.

\section{Pendahuluan}

Seiring dengan berkembangnya teknologi informasi dan komunikasi, televisi menjadi media massa yang paling besar pengaruhnya. Hal ini dikarenakan pengaruh televisi melalui media audio visual-nya dapat langsung diterima oleh pemirsa. Pentingnya peranan media dalam proses komunikasi, disebabkan efisiensinya dalam mencapai komunikan. Surat kabar, radio, atau televisi misalnya, merupakan media yang efisien dalam mencapai komunikan dalam jumlah yang amat banyak. Jelas efisien karena, dengan menyiarkan sebuah pesan satu kali saja, sudah dapat tersebar luas kepada khalayak yang begitu banyak jumlahnya; bukan saja jutaan, melainkan puluhan, bahkan ratusan juta.

Makin maraknya siaran televisi saat ini, membuat makin besar pula kemungkinan efek yang ditimbulkan dari pesan yang disampaikan. Selama ini televisi cenderung dikenal membuat efek buruk (antisosial) tanpa melihat bahwa televisi juga dapat membuat efek positif (prososial). Dilihat dari fungsinya, komunikasi massa mem-punyai beberapa fungsi yakni pengawasan (surveillance), penafsiran (interpretation), penghubung (linkage), penerusan nilai-nilai (transmission of values), dan hiburan (entertainment). Penelitian ini memfokuskan pada fungsi komunikasi massa dalam televisi dengan mengambil Program Acara 'Bukan Empat Mata'di TRANS 7 karena program acara tersebut sangat populer dan diminati oleh masyarakat.

\section{Tinjauan Pustaka}

1. Komunikasi

Pengertian komunikasi secara umum 
Setiap orang yang hidup dalam masyarakat, sejak bangun tidur sampai tidur lagi, secara, kodrati selalu terlibat dalam komunikasi. Terjadinya komunikasi sebagai konsekuensi hubungan sosial (social relations). Masyarakat paling sedikit terdiri dari dua (2) orang yang saling berhubungan satu sama lain yang, karena berhubungan, menimbulkan interaksi sosial (social interaction). Adapun unsur unsur dalam komunikasi adalah sebagai berikut :

a. Sumber

Semua peristiwa komunikasi akan melibatkan sumber sebagai pembuat atau pengirim pesan. Dalam komunikasi antar personal, sumber bisa terdiri dari 1 (satu) orang maupun dalam bentuk kelompok, misalnya partai, organisasi / lembaga. Sumber sering disebut pengirim, komunikator, atau source, sender atau encoder. Sebagai pelaku utama dalam proses komunikasi, komunikator memegang peranan yang sangat penting, terutama dalam mengendalikan jalan-nya komunikasi.

b. Pesan

Pesan yang dikirim oleh komunikator terdiri dari rangkaian simbol dan kode. Simbol merupakan lambang yang memiliki suatu objek, sedangkan kode adalah seperangkat simbol yang telah disusun secara sistematis dan teratur sehingga memiliki arti. Simbol-simbol yang digunakan selain sudah ada yang diterima menurut konvensi internasional, seperti simbol lalu lintas, alfabet latin, simbol matematika, juga terdapat simbol-simbol lokal yang hanya bisa dimengerti oleh kelompok-kelompok masyarakat tertentu.

c. Media

Media adalah alat atau sarana yang digunakan untuk menyampaikan pesan dari sumber kepada penerima.

d. Penerima

Penerima adalah pihak yang menjadi sasaran pesan yang dikirim oleh sumber. Penerima bisa terdiri dari satu orang atau lebih, bisa dalam bentuk kelompok, partai atau negara. Penerima biasa disebut dengan berbagai macam istilah seperti khalayak, sasaran, komunikan, atau juga audience, receiver.

e. Pengaruh

Semua peristiwa komunikasi yang dilakukan secara terencana mempunyai tujuan, yakni mempengaruhi khalayak atau penerima. Pengaruh atau efek adalah perbedaan antara apa yang dipikirkan, dirasakan dan dilakukan oleh penerima sebelum dan sesudah 
menerima pesan (Stuart, 1988). Pengaruh dapat dikatakan mengena jika $\mathrm{P}=\mathrm{T}$ (P merupakan perubahan yang terjadi pada penerima, sedangkan $\mathrm{T}$ tujuan yang diinginkan komunikator). Pengaruh juga ditentukan oleh sumber, pesan, media, dan penerima $(\mathrm{P}=\mathrm{S} / \mathrm{P} / \mathrm{M} / \mathrm{P})$. Pengaruh bisa terjadi dalam bentuk:

- Perubahan pengetahuan Pada tingkat pengetahuan, pengaruh bisa terjadi dalam bentuk perubahan persepsi (cara pandang terhadap suatu obyek) dan perubahan pendapat (penilaian terhadap suatu obyek).

- Perubahan sikap

Perubahan sikap merupakan perubahan internal pada diri seseorang dalam bentuk prinsip, sebagai hasil evaluasi yang dilakukannya terhadap suatu obyek, baik yang terdapat di dalam/di luar dirinya.

- Perubahan perilaku

Perubahan perilaku adalah perubahan yang terjadi dalam bentuk tindakan

f. Umpan Balik

Sebenarnya umpan balik adalah pengaruh yang langsung diterima oleh sumber dari penerima. Umpan balik bisa berupa data, pendapat, komentar, maupun saran.

g. Lingkungan

Lingkungan atau situasi

merupakan faktor-faktor

tertentu yang dapat

mempengaruhi jalannya

komunikasi.

Pengertian komunikasi massa yang dikemukakan oleh Joseph A. DeVito, ditengarai dari dua unit penentu komunikasi massa, yaitu sbb: Pertama, komunikasi massa adalah komunikasi yang ditujukan kepada massa, kepada khalayak yang luar biasa banyaknya. Kedua, komunikasi massa adalah komunikasi yang disalurkan pemancar - pemancar yang audio dan/atau visual.

Jallaludin Rakhmat merangkum definisi-definisi komunikasi massa diatas menjadi : "Komunikasi massa diartikan sebagai jenis komunikasi yang ditujukan kepada sejumlah khalayak yang tersebar, heterogen, dan anonim melalui media cetak atau elektronik sehingga pesan yang sama dapat diterima secara serentak dan sesaat"

Fungsi Komunikasi Massa

Fungsi komunikasi massa menurut Dominick:

1. Surveillance (pengawasan)

Fungsi pengawasan komunikasi massa dibagi dalam bentuk utama : 

- Warning or beware surveillance (pengawasan peringatan)
Fungsi pengawasan peringatan terjadi ketika media massa menginformasikan tentang ancaman dari angin topan, meletusnya gunung merapi, kondisi yang memprihatinkan, tayangan inflasi atau adanya serangan militer.
- Instrumental surveillance (pengawasan instrumental)
Fungsi pengawasan instrumental adalah menyampaikan atau menyebarkan informasi yang mempunyai kegunaan atau dapat membantu khalayak dalam kehidupan sehari- hari.

\section{b.Interpretation (penafsiran)}

Fungsi penafsiran hampir mirip dengan fungsi pengawasan. Media massa tidak hanya memasok fakta dan data, tetapi juga memberikan penafsiran terhadap kejadian-kejadian penting. Tujuan penafsiran media ingin mengajak para pembaca atau pemirsa untuk memperluas wawasan dan membahasnya lebih lanjut dalam komunikasi antarpersona atau komunikasi kelompok. c. Linkage (keterkaitan)

Media massa dapat menyatukan anggota masyarakat yang beragam, sehingga membentuk linkage (pertalian) berdasarkan kepentingan dan minat yang sama tentang sesuatu.

d. Transmission of values (penyebaran nilai)

Fungsi penyebaran nilai tidak kentara. Fungsi ini juga disebut socialization (sosialisasi). Sosialisasi mengacu pada cara, di mana individu mengadopsi prilaku dan nilai kelompok.

e. Entertainment (hiburan)

Tidak dapat dipungkiri bahwa pada kenyataanya hampir semua media menjalankan fungsi hiburan. Fungsi media massa sebagai fungsi menghibur tiada lain tujuannya adalah untuk mengurangi ketegangan pikiran khalayak, karena dengan membaca barita-berita ringan atau melihat tayangan hiburan di televisi dapat membuat pikiran khalayak segar kembali.

3. Fungsi komunikasi massa secara umum, adalah sbb:

a. Fungsi Informasi

Fungsi memberikan informasi ini diartikan bahwa media massa adalah penyebar informasi bagi pembaca, pendengar, atau pemirsa. Berbagai informasi dibutuhkan oleh khalayak media massa yang bersangkutan sesuai dengan kepentingannya. 
b. Fungsi Pendidikan

Media massa merupakn sarana pendidikan bagi khalayaknya (mass education). Karena media massa banyak menyajikan hal-hal yang sifatnya mendidik. Salah satu cara mendidik yang dilakukan madia massa adalah melalui pengajaran nilai, etika, serta aturan- aturan yang berlaku kepada pemirsa atau pembaca. Media massa melakukannya melalui drama, cerita, diskusi dan atikel.

c. Fungsi Mempengaruhi Fungsi memengaruhi dari media massa secara implisit terdapat pada tajuk atau editorial, features, iklan, artikel, dan sebagainya. Khalayak dapat terpengaruh oleh iklan-iklan yang ditayangkan telavisi ataupun surat kabar.

\section{Televisi}

Televisi adalah media audio visual penyampai pesan dalam komunikasi yang menghubungkan antara komunikator dengan komuikannya melalui salura yang terhubung secara mekanik.

\section{Metodologi Penelitian}

1. Jenis Data

Data yang digunakan dalam pelitianini adalah data primer, yaitu data yang diperoleh secara langsung dari obyek penelitian dan data sekunder, yakni data yang diperoleh dari buku maupun litertatur lainnya sebagai pelengkap dalam proposal penyusunan peelitian ini.

2. Metode Pengumpulan Data

a. Metode Studi Pustaka, yaitu metode pengumpulan data melalui pemahaman literatur maupun buku dan juga browsing internet sebagai acuan untuk menntukan landasan teori.

b. Metode Observasi atau pengamatan, yaitu pengumpulan data dengan melakukan pengamatan dan pencatatan secara langsung mengenai halhal yang diselidiki.

\section{Hasil dan Pembahasan}

Penelitian ini menetapkan 30 responden terdiri dari 25 mahasiswa dan 5 dosen/kaum intelektual yang berbeda latar belakang disiplin ilmunya. Dengan disiplin ilmu yang berbeda, diharapkan memperkaya hasil penelitian. Untuk hasil penemuan penelitian, diantaranya: 90\% (22 mahasiswa, 5 dosen) pernah menonton program acara 'Bukan Empat Mata' di Trans TV dan sisanya 10\% (3 mahasiswa) tidak pernah menonton program acara 'Bukan Empat Mata'. Lalu 90\% (25 mahasiswa, 2 dosen) tercatat bahwa melalui program acara 'Bukan Empat Mata', mereka mendapat sesuatu yang menghibur dan 10\% (3 dosen) tidak memperoleh sesuatu yang menghibur. 
Terdapat $60 \%$ responden (15 mahasiswa, 3 dosen) menyatakan kalau segala tingkah laku Tukul Arwana sebagai Pembawa Acara 'Bukan Empat Mata' membuat mereka terhibur, sementara sisanya mengatakan tidak. $100 \%$ responden menuturkan mereka tidak menyediakan waktu khusus untuk menonton program acara ini. Kemudian, sebanyak $70 \%$ subjek penelitian (19 mahasiswa, 2 dosen) mengakui bintang tamu dan materi diskusi dari 'Bukan Empat Mata' juga merupakan salah satu faktor khalayak tertarik untuk menonton acara tersebut. Tercatat $100 \%$ mereka sepakat kalau setiap kali menonton program acara ini, tidak bersama dengan teman-teman, tetapi sendirian. $100 \%$ sumber data mengakui memperoleh nilai pengetahuan yang baru setiap menonton program acara tersebut. Mereka (100\%) juga setuju bahwa materi isi acara 'Bukan Empat Mata' lebih mengedepankan originalitas.

Seluruh responden, ditunjukkan dengan cakupan jumlah $100 \%$ mereka tidak fokus pada program acara 'Bukan Empat Mata', selama menyaksikan acara ini. Terkadang mereka menonton acara tersebut sambil mengerjakan hal yang lain, sehingga beberapa dari mereka (15 mahasiswa) tidak dapat menginterpretasikan dengan baik makna dari materi diskusinya. Tercatat pula $100 \%$ responden dari profesi dosen mengatakan kalau 'Bukan Empat Mata' bukan program acara terfavorit mereka, sehingga program ini tidak bisa dijadikan sebagai inspirator atau motivator dalam kehidupannya seharihari. Ada yang memfavoritkan program berita, olahraga, seni dan budaya serta film sebagai program unggulan masingmasing subjek penelitian. Setelah menjawab poin diskusi itu, lalu sebanyak $80 \%$ responden (20 mahasiswa dan 4 dosen) sepakat tidak setuju dengan pernyataan bahwa mereka dahulu mengetahui pertama kali program acara 'Bukan Empat Mata' dari teman atau saudaranya, sisanya mengamini penjelasan dari periset.

Fokus penelitian ini menuturkan pertama kali mendengar program televisi tersebut, setelah menyaksikan sendiri acaranya. Selanjutnya, $100 \%$ sampel studi mengakui pula tidak pernah menyampaikan pendapat (via telepon ataupun internet) tentang sesuatu atau informasi yang didiskusikan dalam acara yang digawangi oleh Tukul Arwana. Mereka juga setuju kalau fungsi media sebagai pengawas sosial (surveillance function), sebagai pemberi dan penyedia informasi yang menghibur dan fungsi penghubung (communication function) antara media dengan khalayak, tercermin pada program acara 'Bukan Empat Mata'. Sayangnya para subjek penelitian ini tidak menonton setiap episodenya.

Sementara itu, para responden melihat adanya kecenderungan stasiun tv lain yang menduplikasi isi program ini, dengan judul acara yang berbeda-beda. Misalnya; program acara di Indosiar dimana Indro sebagai presenternya. Inti dari format diskusinya tidak jauh berbeda dengan acara yang dibawakan oleh Tukul. Akhir dari data penelitian ini berupa fakta bahwa separuh responden (15 mahasiswa) mengakui sebagai pemirsa program acara 'Bukan Empat Mata' yang loyal, sisanya mengatakan sebaliknya.

\section{Kesimpulan}

Berdasarkan hasil penelitian, dapat terlihat bahwa program acara 'Bukan Empat Mata' di Stasiun TRANS TV terdapat fungsi komunikasi massanya, yaitu berfungsi sebagai pengawas sosial (surveillance 
function/fungsi media sebagai pemberi dan penyedia informasi yang menghibur ke khalayak) dan juga mempunyai fungsi penghubung (linkage function) antara media dengan khalayak. Tercatat pula $50 \%$ responden (15 mahasiswa) mengakui sebagai pemirsa program acara 'Bukan Empat Mata' yang loyal, sisanya (5 dosen) mengatakan dalam hal yang sebaliknya.

\section{Daftar Pustaka}

Effendy, Onong Uchjana. 2006. Ilmu Komunikasi: Teori dan Praktek. Bandung: PT. Remaja RosdaKarya.

Effendy, Onong Uchjana. 2004. Dinamika Komunikasi. Bandung: PT. Remaja RosdaKarya.

Cangara, Hafied. 1998. Pengantar Ilmu Komunikasi. Jakarta: PT. Raja Grafindo Perkasa.

Mulyana, Dedy. 2007. Ilmu Komunikasi: Suatu Pengantar. Bandung: PT. Remaja RosdaKarya.

Basrowi, M.S. 2005. Pengantar Sosiologi. Bogor: PT. Ghalia Indonesia.

Mulyana, Deddy. 2002. Nuansanuansa Komunikasi, Bandung: PT. Remaja Rosdakarya.

Wright, Charles R. Penyunting, Rakhmat, Jallaludin. 2002. Sosiologi Komunikasi Massa. Bandung: PT. Remaja Rosdakarya.

Winarso, Heru Puji. 2005. Sosiologi Komunikasi Massa. Jakarta: Prestasi Pustaka.

basithjournalist.com 